\title{
Pathogenicity studies on a Vibrio anguillarum- related (VAR) strain causing an epizootic in Argopecten purpuratus larvae cultured in Chile
}

\author{
C. Riquelme ${ }^{1}$, G. Hayashida ${ }^{1}$, A. E. Toranzo ${ }^{2}$, J. Vilches ${ }^{1}$, P. Chavez ${ }^{1}$ \\ ${ }^{1}$ Departamento de Acuicultura, Facultad de Recursos del Mar, Universidad de Antofagasta, PO Box 170, Antofagasta, Chile \\ ${ }^{2}$ Departamento de Microbiología y Parasitología, Facultad de Biología, Universidad de Santiago de Compostela, \\ E-15706 Santiago de Compostela, Spain
}

\begin{abstract}
A Vibrio anguillarum-related (VAR) strain, isolated in pure culture from an epizootic in a commercial hatchery producing Argopecten purpuratus, was characterized, and its potential pathogenicity to veliger larvae of $A$. purpuratus determined. Experimental challenges indicated that the bacterium affects larval survival at concentrations of $10^{4}$ to $10^{8}$ cells ml ${ }^{-1}$ The effect of water quality and temperature on pathogenicity was also evaluated. Larval survival in seawater filtered through $5 \mu \mathrm{m}$ pore-size membranes was $45.6 \%$, whereas using seawater passed through 1 and $0.2 \mu \mathrm{m}$ filters, larval survival increased to 66.4 and $30.4 \%$ respectively. Temperature also affected pathogenicity as larval survival at $15^{\circ} \mathrm{C}$ for $24 \mathrm{~h}$ was $69.3 \%$ but decreased to 30 and $26.9 \%$ at 20 and $25^{\circ} \mathrm{C}$, respectively. Toxic activity was found in cell-free supernatant of bacterial culture. Larval survival was reduced to 68.9 and $36.4 \%$ after 20 and $40 \%(\mathrm{v} / \mathrm{v})$ of supernatant, respectively, was added to the rearing water. These results suggest that exotoxins produced by the VAR strain play an important role in its pathogenicity for scallop larvae.
\end{abstract}

KEY WORDS: Argopecten purpuratus - Larvae - Vibrio anguillarum-related (VAR) - Pathogenicity . Exotoxins

\section{INTRODUCTION}

Great importance is attributed to vibrios as pathogens of bivalves because of their association with high mortalities of larval cultures with consequent economic losses to the hatcheries (DiSalvo et al. 1978, Elston \& Leibovitz 1980, Jeffries 1982, Brown 1983, Nottage \& Birkbeck 1986, 1990, Lodeiros et al. 1987 , Bourne et al. 1989, Navarro et al. 1991). Thus, there is an urgent need to develop methods for controlling sudden outbreaks of vibriosis in commercial hatcheries.

The occurrence of epizootics caused by vibrios in bulk bivalve cultures may be related to their high concentration in the environment, since low concentrations of vibrios do not necessarily imply a risk for larval culture (Jeffries 1982), Sudden proliferation of members of the Vibrionaceae associated with severe larval mortalities generally occurs in summer when organic matter increases in the sea and the seawater tempera- ture exceeds $18^{\circ} \mathrm{C}$ (Sinderman 1990). In view of this, parameters such as the concentration of organic matter and temperature should be monitored during larval culture since they could be important contributing factors in the proliferation of potential pathogenic vibrios in a culture system.

Although vibriosis caused by Vibrio anguillarum and $V$. tubiashii has been considered the most important bacterial infection limiting the production of marine fish and shellfish throughout the world (see review by Toranzo \& Barja 1990), other vibrios exist in the environment that are taxonomically and serologically related to these 2 species (Bryant et al. 1986, Fouz et al. 1990). These other variants have been traditionally considered to be of no pathogenic significance, but have been also associated with disease in larval and adult stages of marine fish (Masumura et al. 1989, Fouz et al. 1990, Toranzo et al. 1990, 1993, Myhr et al. 1991, Toranzo \& Barja 1993) and shellfish (Baticados et al. 
1990, Lavilla-Pitogo et al. 1990, Paillard \& Maes 1990, Castro et al. 1992, Fujiwara et al. 1993). These vibrios correspond mainly to different biotypes of $V$. splendidus and $V$. pelagius species and can be grouped under the designation ' $V$. anguillarum-like' or $V$. anguillarum-related (VAR) organisms (Larsen 1985. Fouz et al. 1990, Toranzo \& Barja 1990, Myhr et al. 1991, Pazos et al. 1993).

The pathogenicity of some vibrios isolated from molluscs (oysters) has been assumed to be due to their invasive capacity and/or their ability to produce exotoxin(s) (DiSalvo et al. 1978, Elston \& Leibovitz 1980, Elston et al. 1981, Birkbeck et al. 1987).

The aim of the current study was to evaluate the effect of temperature and water quality on the pathogcnic capacity of a VAR strain isolated in pure culture from an epizootic in a commercial hatchery for Argopecten purpuratus (Lamarck, 1819). In addition, the role of exotoxins produced by this Vibrio strain on larval survival was investigated.

\section{MATERIALS AND METHODS}

Bacterial isolation. In a hatchery located in northern Chile $\left(27^{\circ} 5^{\prime} 42^{\prime \prime} \mathrm{S}, 69^{\circ} 51^{\prime} 48^{\prime \prime} \mathrm{W}\right)$ massive larval mortalities occur in spring-summer. On one of these occasions, culture tanks with more than $90 \%$ of larvae on the bottom were sampled. Swimming and bottom larvae were netted and washed with sterile seawater, then homogenized using a tissue grinder and spread on TCBS (thiosulfate-citrate-bile sucrose agar) (Oxoid) and marine general medium ST10 (Ishida et al. 1986). In addition, the bacterial flora of the hatchery water supply was determined: unfiltered, seawater in sedimentation tanks, filtered and UV treated seawater, and water from larval culture ponds. The bacterial flora of microalgal cultures (stock and production batches) used as larval food was also determined. All samples were spread in triplicate on TCBS and ST10 media and incubated at $20^{\circ} \mathrm{C}$ for $48 \mathrm{~h}$ on TCBS and for $7 \mathrm{~d}$ on ST10. Additionally, broodstock gonads were extracted and washed externally with $1 \%$ benzalkonium chloride. A small incision was made through the surface of the gonads with a heat sterilized scalpel. Gonad contents were removed with sterile Pasteur pipettes, then homogenized and spread on TCBS medium.

Biochemical and serological characterization. Pure cultures of the bacteria isolated from moribund larvae were subjected to standard morphological, physiological and biochemical tube and plate tests according to the procedures of West \& Colwell (1984), Bryant et al. (1986), Fouz et al. (1990) and Hansen \& Sorheim (1991). Plates and tubes were incubated at $22^{\circ} \mathrm{C}$ for up to $7 \mathrm{~d}$. In addition, the commercial miniaturized API-
$20 \mathrm{E}$ system (Analytab) was employed using half strength seawater as diluent, and the results were scored after $48 \mathrm{~h}$ at $22^{\circ} \mathrm{C}$.

The taxonomic position of the Vibrio strain recovered in pure culture from all diseased larvae was determined following the criteria of West \& Colwell (1984), Bergey's Manual of Systematic Bacteriology (1984, 1986), Bryant et al. (1986), Myhr et al. (1991) and Austin \& Lee (1992).

Drug resistance patterns were determined by the disc diffusion method (Barry \& Thornsberry 1991) on Mueller-Hinton agar (bioMerieux) supplemented with $1.5 \% \mathrm{NaCl}$, using the following antimicrobial agents ( $\mu \mathrm{g}$ disc $^{-1}$ ): ampicillin (10), streptomycin (10), chloramphenicol (30), tetracycline (30), oxytetracycline (30), Erythromyciñ (15), käiañycin (30), oxuinic aciu (2), Furazolidone (300), novobiocin (5) and trimethoprimsulphamethoxazole (23.75-1.25). The vibriostatic agent O/129 (150) was employed only for taxonomic purposes.

Serological analysis was conducted by the slideagglutination test as described by Sørensen \& Larsen (1986) and Toranzo et al. (1987), using the thermostable bacterial ' $O$ ' antigens and rabbit antisera raised against the $10^{\prime} \mathrm{O}$ ' serotypes (from $\mathrm{O} 1$ to $\mathrm{O} 10$ ) of Vibrio anguillarum (Sørensen \& Larsen 1986), V. tubiashii EX1 (Lodeiros et al. 1987) and $V$. splendidus biovar I ATCC 25914.

Pathogenicity studies. Virulence assays were performed to determine the pathogenicity of the Vibrio strain isolated as pure culture from moribund larvae. Healthy larvae of Argopecten purpuratus obtained from the hatchery were used for these assays.

Pathogenicity of the isolated strain was determined applying the following variables: (1) bacterial concentration, (2) water quality and (3) temperature. The assays were performed in triplicate according to a modification of methodology described by Brown (1983). Argopecten purpuratus larvae were added (at 2 larvae $\mathrm{ml}^{-1}$ ) to sterile seawater filtered through $0.2 \mu \mathrm{m}$ membranes (Millipore) contained in cell culture chambers of $15 \mathrm{ml}$ capacity.

(1) Effect of bacterial concentration: Bacteria cultured in ST10 broth were washed by centrifugation (3840 $\times g$ for $15 \mathrm{~min}$ ) and suspended in Marine Saline Solution (MSS) (Austin 1988). Bacterial cells in this suspension were stained with $1 \mu \mathrm{g} \mathrm{ml} \mathrm{m}^{-1}$ of DAPI $\left(4^{\prime}, 6-\right.$ diamidino-2-phenylindole) (Porter \& Feig 1980) and counted under epifluorescence microscope (Austin 1988). Dilutions of the cell suspension were then added to the larvae. Final concentrations of Vibrio used were ca $10^{4}, 10^{5}, 10^{6}, 10^{7}$ and $10^{8}$ cells $\mathrm{ml}^{-1}$. Chambers without addition of bacteria were used as controls. These bioassays were carried out at $20^{\circ} \mathrm{C}$, and larval survival at 19 and 24 h was recorded 
(2) Effect of water quality: Argopecten purpuratus larvae were suspended in seawater filtered through different pore-size membranes: (a) $5 \mu \mathrm{m}$ (Nytal), (b) $1.2 \mu \mathrm{m}$ (Millipore) and (c) $0.2 \mu \mathrm{m}$ (Millipore). A final concentration of bacteria $10^{h}$ cells $\mathrm{ml}^{1}$ was added to each chamber Controls without bacteria were used for each treatment. Larval survival was recorded at 10, 19 and $24 \mathrm{~h}$.

(3) Effect of temperature: To evaluate the effect of temperature on the pathogenicity of this strain, a bacterial concentration of $10^{6}$ cells $\mathrm{ml}^{-1}$ was added to each chamber containing larvae in filtered $(0.2 \mu \mathrm{m})$ seawater. The temperatures used for bioassays were 15 , 20 and $25^{\circ} \mathrm{C}$. Controls without bacteria were used for each treatment. Larval survival was recorded at 10,19 and $24 \mathrm{~h}$.

Effect of cell-free supernatant of bacterial culture on larval survival. Bacterial cultures in ST10 were centrifuged for $15 \mathrm{~min}$ at $3840 \times \mathrm{g}$. The supernatant was filtered through $0.2 \mu \mathrm{m}$ membranes (Millipore), and added at 20 and $40 \% \mathrm{v} / \mathrm{v}$ to each chamber containing larvae in filtered $(0.2 \mu \mathrm{m})$ seawater. Chambers without filtered supernatant and with $10^{5}$ and $10^{6}$ viable cells $\mathrm{ml}^{-1}$ of bacteria were used as controls. Larvae were maintained in these conditions at $20^{\circ} \mathrm{C}$ and survival recorded after $24 \mathrm{~h}$.

Record of larval survival. In all the experimental trials, larval survival was quantified by means of observation of the organisms under a microscope. Larvae on the bottom of chambers that showed no apparent movement, closed valves and no velar activity were considered dead.

The presence of bacteria on moribund larvae was verified by epifluorescence microscopy using DAPI staining

All assays were repeated at least twice. Results were analyzed using the statistical $G$ test (Zar 1984).

Table 1 Vibrios and total culturable bacteria (CFU $\mathrm{ml}^{-1}$ ) in different samples analyzed in the hatchery

\begin{tabular}{|c|c|c|}
\hline Samples & Vibrio (TCBS) & Total bacteria (ST10) \\
\hline Entrance seawater & $2.0 \times 10^{2}$ & $9.3 \times 10^{3}$ \\
\hline Sedimentation tanks & $1.0 \times 10^{2}$ & $4.9 \times 10^{3}$ \\
\hline $\begin{array}{l}\text { Filtered water } \\
\text { treated with UV }\end{array}$ & $<10^{a}$ & $7.0 \times 10^{2}$ \\
\hline $\begin{array}{l}\text { Water from larval } \\
\text { tanks }\end{array}$ & $1.2 \times 10^{4}$ & $1.3 \times 10^{4}$ \\
\hline Microalgae & $<10^{\mathrm{a}}$ & nd \\
\hline Breeders & $2.4 \times 10^{3 b}$ & nd \\
\hline \multicolumn{3}{|c|}{ 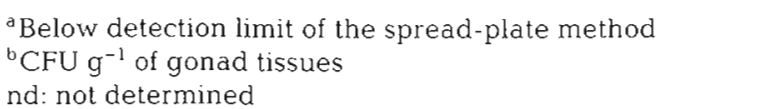 } \\
\hline
\end{tabular}

\section{RESULTS}

Results of bacteriological analysis of samples in the hatchery are presented in Table 1 The filtered and UV-treated water entering larval culture tanks contained a low bacterial concentration and undetectable number of Vibrio spp. However, after the filtration and UV treatment, the Vibrio populations increased in the culture tanks, reaching values of $92.3 \%$ of the total culturable bacteria. This increase is very high compared to the $2.2 \%$ composition of vibrios present in the intake seawater. In microalgal cultures used as food for the larvae, Vibrio strains were also not detected.

Bacteriological analysis of moribund larvae revealed the presence of a Vibrio strain in pure culture, which was identified as $V$. anguillarum related (VAR) (Table 2). This isolate shared characteristics with $V$. anguillarum, $V$. tubiashii and $V$. splendidus biovar I. However, serological tests indicated that this isolate did not share antigens with the reference strains of these 3 species. The bacterium was resistant to several antimicrobial agents (Table 2)

The bioassays on the pathogenicity of the VAR to larvae showed that a concentration of $10^{6}$ cells $\mathrm{ml}^{-1}$ was necessary to produce a decrease in larval survival (Table 3) The highest mortality $10 \%$ larval survival) was recorded at $24 \mathrm{~h}$ with a concentration of $10^{8}$ cells $\mathrm{ml}^{-1}(\mathrm{p}<0.05)$. However, with a bacterial concentration of $10^{4}$ cells $\mathrm{ml}^{-1}$ survival was $94 \%$ at $24 \mathrm{~h}$, not significantly different from the control $(p<0.05)$. The number of colony-forming units (CFU) in the initial bacterial inoculum was determined in selective medium (TCBS) and the number of culturable Vibrio strain corresponded to ca $0.1 \%$ of the total cells.

The results of different treatments of water filtration indicated that in seawater filtered through $5 \mu \mathrm{m}$ poresize membranes, larval survival decreased to $67.3 \%$ in $10 \mathrm{~h}$ and $45.6 \%$ in $24 \mathrm{~h}$ (Fig. 1A). However, using water filtered through $1 \mu \mathrm{m}$ and $0.2 \mu \mathrm{m}$ pore-sizes, larval survival of 66.4 and $80.4 \%$ respectively was reached at $24 \mathrm{~h}$. Larval survival in these 3 treatments of seawater to which the VAR was added was significantly lower $(\mathrm{p}<0.05$ ) than in the respective controls (Fig. 1B).

The pathogenicity of the VAR to larvae of Argopecten purpuratus was affected by culture temperature (Fig. 2). At $25^{\circ} \mathrm{C}$ the pathogenic effect was considerable, because larval survival was reduced to 36.8 and $26.9 \%$ at 10 and 24 h respectively (Fig. $2 \mathrm{~A}$ ). In contrast, in the controls (without bacteria added) survival of larvae greater than $70 \%$ was observed at both times (Fig. 2B). At $20^{\circ} \mathrm{C}$, larval survival of 70.4 and $30 \%$ at 10 and $24 \mathrm{~h}$ respectively was observed, both of which were lower ( $p<0.05$ ) than controls (Fig. $2 B$ ).

In the presence of the VAR strain, best larval survival $\left(p<0.05\right.$ ) was found at $15^{\circ} \mathrm{C}$, reaching 81.9 and $69.3 \%$ 
Table 2. Identification of Vibrio anguillarum (VAR) strain

\begin{tabular}{|c|c|}
\hline Characteristic & Response \\
\hline Gram stain & - \\
\hline Motility & + \\
\hline Oxidase & + \\
\hline Catalase & + \\
\hline Voges-Proskauer & - \\
\hline Indole production & + \\
\hline Citrate utilization & - \\
\hline $\mathrm{H}_{2} \mathrm{~S}$ production & - \\
\hline $\mathrm{O} / \mathrm{F}$ (glucose) & F \\
\hline Gas from glucose & - \\
\hline Growth at $5^{\circ} \mathrm{C}$ & - \\
\hline $15^{\circ} \mathrm{C}$ & + \\
\hline $25^{\circ} \mathrm{C}$ & + \\
\hline $37^{\circ} \mathrm{C}$ & - \\
\hline $42^{\circ} \mathrm{C}$ & - \\
\hline Growth in $0 \% \mathrm{NaCl}$ & - \\
\hline $3 \% \mathrm{NaCl}$ & + \\
\hline $5 \% \mathrm{NaCl}$ & + \\
\hline $8 \% \mathrm{NaCl}$ & - \\
\hline $10 \% \mathrm{NaCl}$ & - \\
\hline Growth on TCBS & +yellow \\
\hline Arginine dihydrolase & + \\
\hline Lysine decarboxylase & - \\
\hline Ornithine decarboxylase & - \\
\hline Lipase (Tween 80) & + \\
\hline B-Galactosidase (ONPG) & + \\
\hline Urease & - \\
\hline Gelatinase & + \\
\hline Amylase & + \\
\hline Haemolysis (sheep blood) & + \\
\hline \multicolumn{2}{|l|}{ Acid production from: } \\
\hline Glucose & + \\
\hline Mannose & + \\
\hline Galactose & + \\
\hline Fructose & + \\
\hline Sucrose & + \\
\hline Rhamnose & - \\
\hline Arabinose & - \\
\hline Amygdaline & + \\
\hline Melibiose & - \\
\hline Mannitol & + \\
\hline Inositol & - \\
\hline Sorbitol & - \\
\hline \multicolumn{2}{|l|}{ Sensitivity/resistance to: } \\
\hline $0 / 129$ & $\mathrm{~S}$ \\
\hline Novobiocin & $\mathrm{R}$ \\
\hline Ampicillin & $\mathrm{R}$ \\
\hline Chloramphenicol & I \\
\hline Tetracycline & $\mathrm{R}$ \\
\hline Oxytetracycline & $\mathrm{R}$ \\
\hline Streptomycin & I \\
\hline Erythromycin & $\mathrm{R}$ \\
\hline Kanamycin & I \\
\hline Oxolinic acid & $\mathrm{R}$ \\
\hline Furazolidone & $\mathrm{S}$ \\
\hline Trimethoprim-sulphamethoxazole & $\mathrm{R}$ \\
\hline \multicolumn{2}{|c|}{$\begin{array}{l}\text { F: fermentative strain; } \mathrm{R} \text { : resistant; } \mathrm{S} \text { : sensitive; } \\
\text { I: intermediate }\end{array}$} \\
\hline
\end{tabular}

Table 3. Argopecten purpuratus. Effect of different concentrations of Vibrio anguillarum (VAR) on larval survival

\begin{tabular}{|ccc|}
\hline $\begin{array}{l}\text { Bacterial concentration } \\
\text { added (cells ml }\end{array}$ & & \multicolumn{2}{c|}{ Larval survival } \\
& $19 \mathrm{~h}$ & $24 \mathrm{~h}$ \\
$10^{4}$ & 98 & 95 \\
$10^{5}$ & 98 & 87 \\
$10^{6}$ & 76 & 70 \\
$10^{7}$ & 11 & 3 \\
$10^{8}$ & 0 & 0 \\
Control (no Vibrio added) & 100 & 100 \\
\hline
\end{tabular}

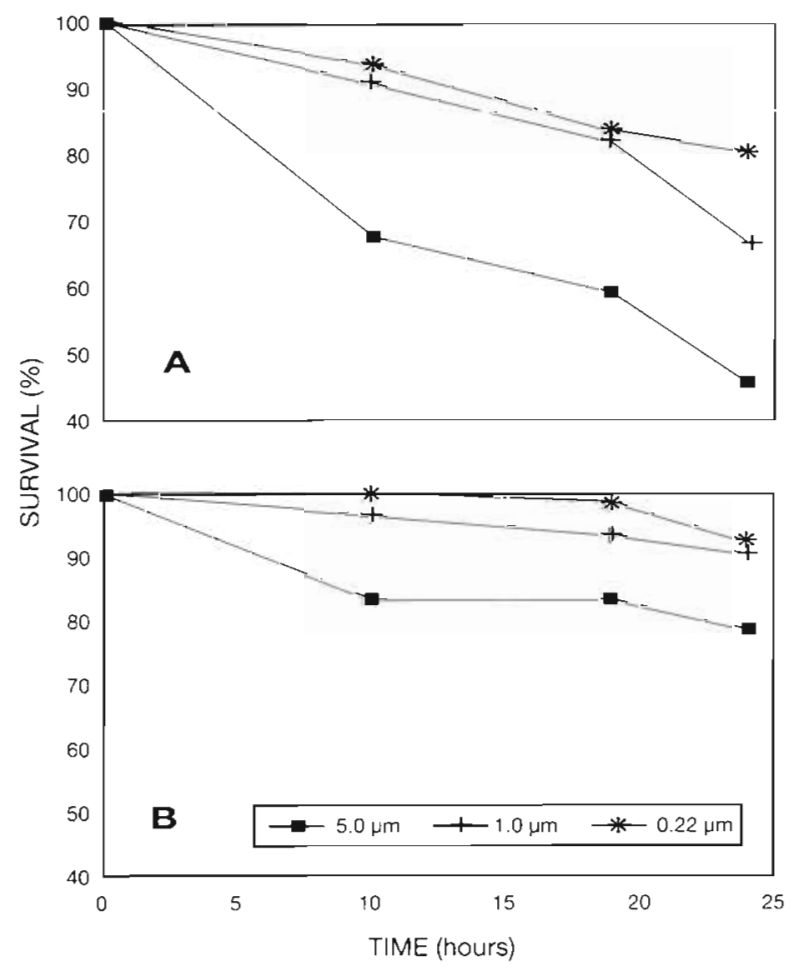

Fig. 1. Argopecten purpuratus. Effect of differential filtration of seawater on larval survival. (A) Larvae with addition of VAR strain; (B) control

at 10 and 24 h, respectively (Fig. 2A). However, at this temperature larval survival in the control was significantly lower than in the tanks containing the Vibrio strain (Fig. 2B).

The addition of cell-free supernatant of Vibrio cultures to tanks of larvae showed a clear lethal effect causing a decrease of larval survival to 68.9 and $36.4 \%$ after $24 \mathrm{~h}$ following addition of 20 and $40 \% \mathrm{v} / \mathrm{v}$ respectively (Fig. 3). These values were significantly lower than those obtained in controls as well as in tanks containing $10^{5}$ viable cells $\mathrm{ml}^{-1}$ Colonization of bacteria was observed on moribund larvae exposed to the VAR strain for $24 \mathrm{~h}$ (Fig. 4). 


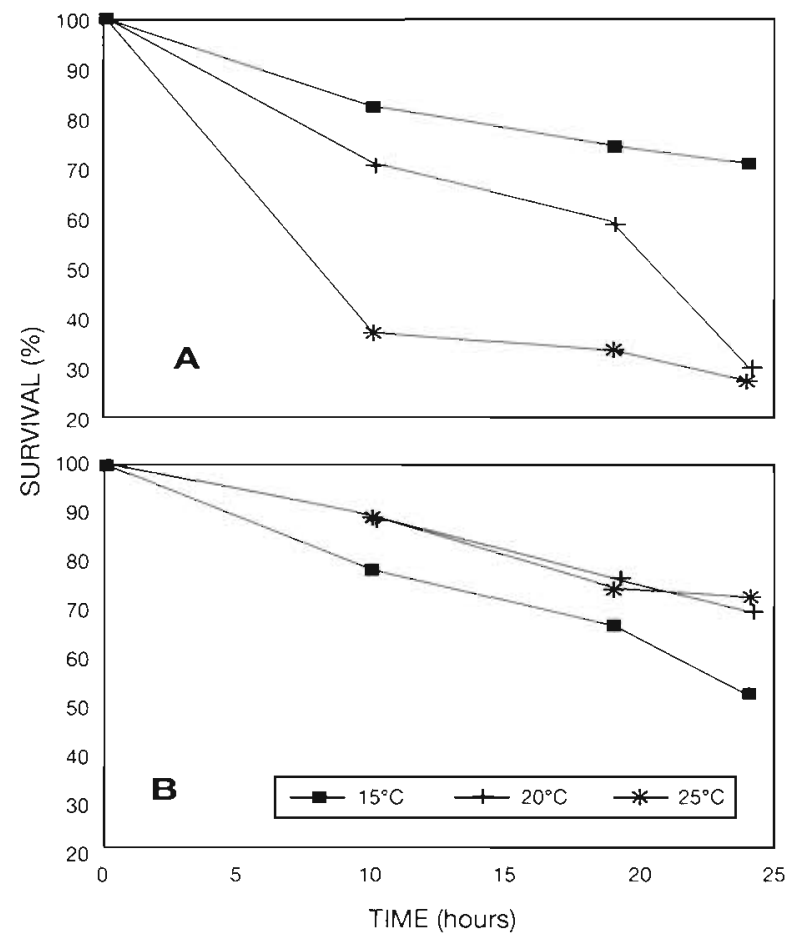

Fig. 2. Argopecten purpuratus. Effect of temperature on larval survival. (A) Larvae with addition of VAR strain; (B) control

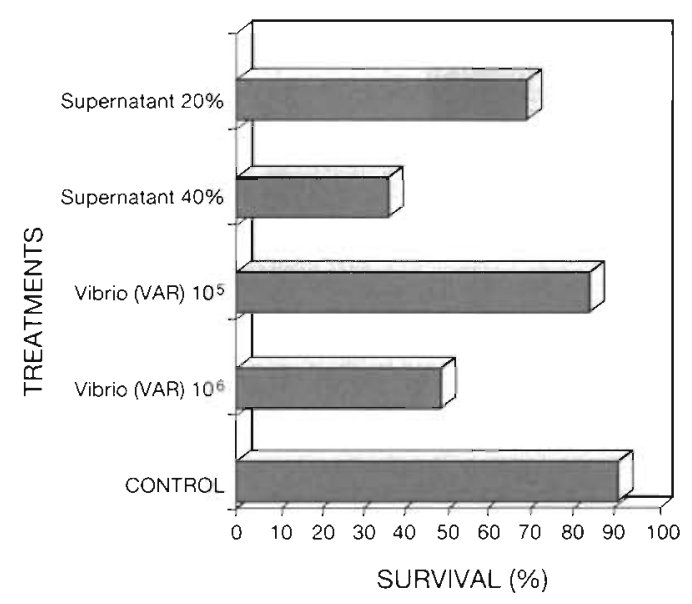

Fig. 3. Argopecten purpuratus. Survival of larvae exposed to: $10^{5}$ and $10^{6}$ cells ml $\mathrm{m}^{-1}$ of vibrios (VAR) and $20 \%$ and $40 \%(\mathrm{v} / \mathrm{v})$ of culture supernatant of this strain

\section{DISCUSSION}

The results of the survey in the hatchery suggest that the probable incorporation route of vibrios to the system could be the broodstock which contained a significant load of vibrios $\left(2.4 \times 10^{3} \mathrm{CFU} \mathrm{g}^{-1}\right)$ in their reproductive organs. Similar findings of vertical transmission of Vibrio strains have been reported previously for Ostrea edulis (Lodeiros et al. 1987) and Argopecten purpuratus (Riquelme et al. 1994).

The microbiological analysis allowed us to identify a VAR strain as responsible for the larval mortalities. In agreement with previous reports (Lodeiros et al. 1987, Myhr et al. 1991, Castro et al. 1992, Pazos et al. 1993) this strain is taxonomically related to Vibrio anguillarum, $V$. tubiashi, and $V$. splendidus. Until now, only 2 occurrences of pathogenic $V$. anguillarum and related strains (VAR) have been reported as responsible for mortalities of mollusc larvae in Chile. $V$. anguillarum has been recovered from Mytilus chilensis (Vial et al. 1988), and VAR organisms were isolated from Argopecten purpuratus and Concholepas concholepes culture (Pazos et al. 1993). The multiresistance to antimicrobial agents of $V$. anguillarum isolated is remarkable (Table 2), and may be attributed to the frequent use of drugs in larval culture in the hatchery. The assays of pathogenicity conducted with this $V$. anguillarum indicated that a concentration of $10^{6}$ cells $\mathrm{ml}^{-1}$ is necessary to cause a pathogenic effect in $A$. purpuratus larvae

The lower larval survival observed in bioassays with seawater filtered through $5 \mu \mathrm{m}$ membranes can be attributed to the increase of this bacterium because of the copiotrophic characteristic of vibrios (West \& Colwell 1984) and by the highest availability of particles and nutrients in this filtered seawater.

The increase of temperature affected the pathogenicity of this Vibrio strain, with $69.3 \%$ larval survival at $15^{\circ} \mathrm{C}$ in $24 \mathrm{~h}$, but 30 and $26.9 \%$ respectively at 20 and $25^{\circ} \mathrm{C}$. These findings may be attributed to the higher temperatures favouring bacterial proliferation. In fact, a typical feature of the majority of Vibrio species is their improved growth at temperatures above $15^{\circ} \mathrm{C}$ (West \& Colwell 1984). Moreover, at $25^{\circ} \mathrm{C}$ the heat stress could adversely affect the larvae and predispose them to Vibrio attack. In rearing scallop larvae, temperatures between 18 and $24^{\circ} \mathrm{C}$ are used (Navarro et al. 1991).

In control cultures larval survival was lower at $15^{\circ} \mathrm{C}$ (Fig. 2B). This could be explained by the fact that $15^{\circ} \mathrm{C}$ is below the optimal temperature for the development of Argopecten purpuratus larvae. However in $15^{\circ} \mathrm{C}$ cultures inoculated with the VAR strain, larval survival was higher than in controls. Apparently the VAR strain is less virulent at $15^{\circ} \mathrm{C}$, and also partially satisfies some nutritional requirements for larval survival. This point requires further investigation.

The overall results for the effects of water quality and temperature on the pathogenicity of the VAR strain in Argopecten purpuratus larvae indicate that both parameters are of great importance for controls against the increase of Vibrionaceae in larval cultures.

The result that the cell-free supernatant of Vibrio cultures decreased the larval survival suggest that a probable exotoxin(s) produced by this strain play a role 

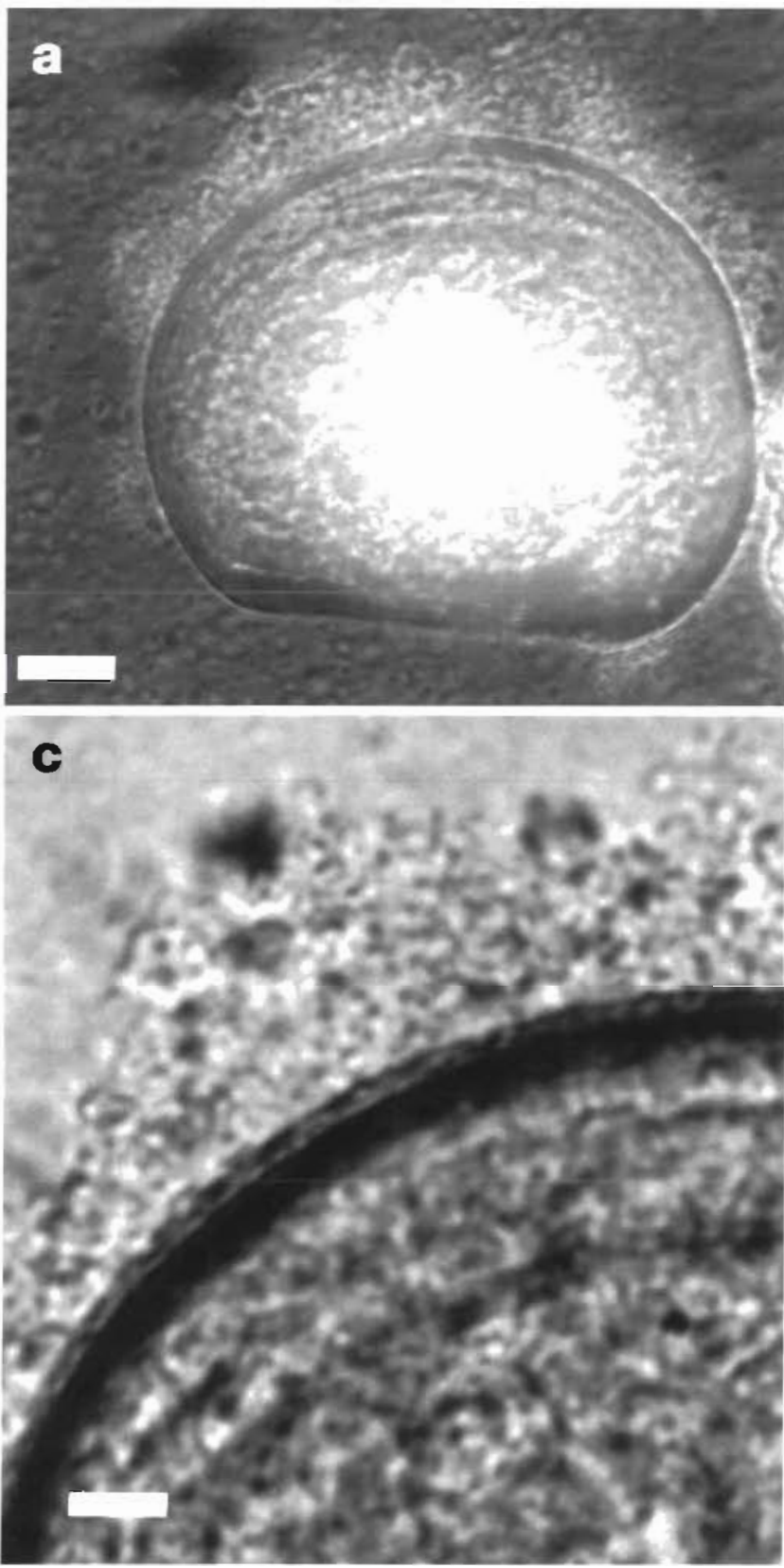

in its pathogenicity. A review of the literature indicates that some species of Vibrio produce toxins that adversely affect mollusc larvae (Brown \& Roland 1984, Nottage \& Birkbeck 1986, 1987).

Epifluorescence microscopy revealed the presence of bacteria colonizing the moribund larvae (Fig. 4). The possibility of direct invasion by the bacterium cannot be ruled out, but needs verification.

Pathogenicity of a bacteria is usually determined by the capacity to release a toxin(s), attack the host or both (Elston \& Leibovitz 1980, Brown \& Roland 1984, Nottage \& Birkbeck 1986, 1987, Birkbeck et al. 1987).

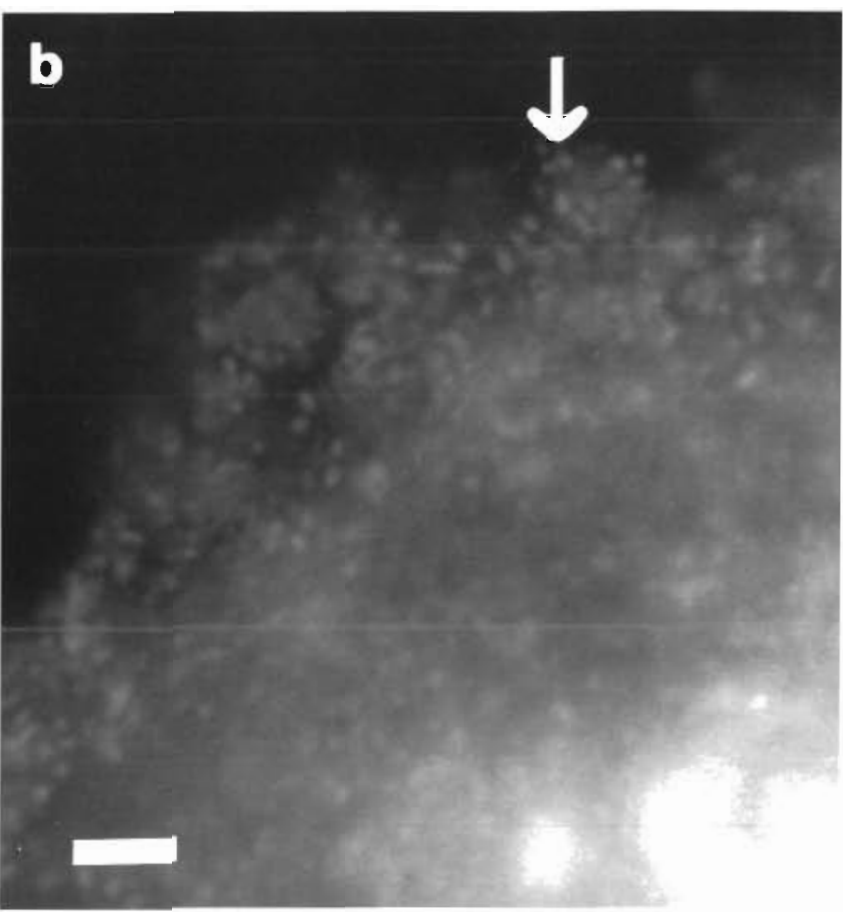

Fig. 4. Argopecten purpuratus. Moribund larvae colonized by the VAR strain. (a) Epifluorescence microscopy and phase contrast; bar $=30 \mu \mathrm{m}$; (b) epifluorescence, arrow shows bacteria; bar $=8 \mu \mathrm{mi}_{\text {i }}$ (c) light microscopy; bar $=8 \mu \mathrm{m}$

However it remains necessary to clarify the mechanism(s) of action that the present VAR strain possesses and to discover the nature and pathogenic effect of extracellular products that makes this bacterium a significant pathogen of Argopecten purpuratus larvae.

Acknowledgements. This investigation was supported by FONDECYT Grant 92-0997 (Chile) to C.R. A.E.T thanks the $\mathrm{EEC}$ for financial support through Grant AQ-1-263 UK-F-E.

\section{LITERATURE CITED}

Austin B (1988) Marine microbiology. Cambridge University Press, Cambridge

Austin B, Lee JV (1992) Aeromonadaceae and Vibnonaceae. In: Board R, Jones D, Skinner FA (eds) Identification methods in applied and environmental microbiology. Blackwell Sci Publ, Oxford, p 163-182

Barry A.L, Thornsberry C (1991) Susceptibility tests: diffusion test procedures. In: Balows A, Hausler $\mathrm{WJ} J$ r, Hermann KL, Isenberg HD, Shadomy HJ (eds) Manual of clinical microbiology. American Society for Microbiology, Washington, DC, p 1117-1125

Baticados MCL, Lavilla-Pitogo CR, Cruz-Lacrerda ER, de la Peña LD. Sunaz NA (1990) Studies on the chemical control of luminous bacteria Vibrio harveyi and $V$ splendidus isolated from diseased Penacus monodon larvae and rearing water. Dis aquat Org 9:133-139 
Bergey's Manual of Systematic Bacteriology (1984, 1986) Williams and Wilkins, Baltimore, Vols 1 and 2

Birkbeck TH, McHenery JG, Nottage AS (1987) lnhibition of filtration in bivalves by marine vibrios. Aquaculture 67 : $247-248$

Bourne N, Hodgson CA, Whyte JNC (1989) A manual tor scallop culture in British Columbia. Can Tech Rep Fish Aquat Sci 1964:215

Brown C (1983) Bacterial diseases in bıvalve larval cultures and their control. In: Berg CJ (ed) Culture of marine invertebrates. Selected readings. Mar Biol Lab Woods Hole 21: $230-242$

Brown C, Roland G (1984) Characterization of exotoxin produced by a shellfish-pathogenic Vibrio sp. J Fish Dis 7 . $117-126$

Bryant TN, Lee JV, West PA, Colwell RR (1986) Numerical classification of species of Vibrio and related genera. J appl Bacteriol 61:437-467

Castro D, Martinez-Manzanares E, Luque A, Fouz B, Morinigo MA, Borrego JJ, Toranzo AE (1992) Characterization of strains related to brown ring disease outbreaks in southwestern Spain. Dis aquat Org 14:229-236

DiSalvo L.H, Blecka J, Zebal R (1978) Vibrio anguillarum and larval mortality in a California coastal shellfish hatchery. Appl environ Microbiol 35:219-221

Elston R, Leibovitz L. (1980) Pathogenesis of experimental vibriosis in larval American oysters, Crassostrea gigas. Can J Fish Aquat Sci 37:964-978

Elston R, Leibovitz L, Relyea D. Zatila J (1981) Diagnosis of vibriosis in a commercial oyster hatchery epizootic: diagnostic tools and management features. Aquaculture 24: $53-62$

Fouz B, Conchas RD, Bolinches JL, Barja JL, Toranzo AE (1990) Relationships among pathogenic Vibrio anguillarum and Vibrio tubiashii with environmental vibrios. In: Perkins FO, Cheng TC (eds) Pathology in manne science. Academic Press, New York, p 77-89

Fujiwara M. Uyeno Y, Iwao A (1993) A Vibrio sp. associated with mortalities in cockle larvae Fulvia mutica (Mollusca: Cardindae). Gyobyo Kenkyu 28:83-89

Hansen GH, Sorheim R (1991) Improved method for phenotypical characterization of marine bacteria. J mucrobiol Meth 13:231-241

Ishida Y, Eguchi M, Kadota H (1986) Existence of obligately oligotrophic bactena as a dominant population in the South China Sea and the West Pacific Ocean. Mar Ecol Prog Ser 30:197-203

Jeffries VE (1982) Three Vibrio strains pathogenic to larvae of Crassostrea virginica and Ostrea edulis. Aquaculture 29 . $201-226$

Larsen JL (1985) Vibrio anguillarum: prevalence of typical and atypical strains in marine recipients with special reference to carbohydrate pollution. Acta vet scand 26 : $449-460$

Lavilla-Pitogo CR, Baticados MCL, Cruz-Lacierda ER, de la Peña LD (1990) Occurrence of luminous bacterial disease of Penaeus monodon larvae in the Philippines. Aquaculture 91:1-13

Lodeiros C, Bolinches J, Dopazo C. Toranzo A (1987) Bacillary necrosis in hatcheries of Ostrea edulis in Spain. Aquaculture 65:15-29

Masumura K, Yasunobu H. Okada N, Muroga K (1989) Isolation of a Vibrio sp. the causative bacterium of intestinal necrosis of Japanese flounder larvae. Fish Pathol 24: $135-141$
Myhr E, Larsen JL, Lillehaug $A$, Gudding $R$, Heum $M$. Hastein $T$ (1991) Characterization of Vibrio anguillarum and closely related species isolated from farmed fish in Norway. Appl environ Microbiol 57:2750-2757

Navarro R, Sturla L. Cordero O. Avendaño M (1991) Chıle: fisheries and aquaculture. In: Shumway $S$ (ed) Scallops: biology, ecology and aquaculture. Chap 14. Elsevier Science Publisher, Amsterdam, p 1001-1015

Nottage AS, Birkbeck TH (1986) Toxicity to marine bivalves of culture supernatant fluids of the bivalve-pathogenic Vibrio strain NCMB 1338 and other marine vibrios. J Fish Dis 9:249-256

Nottage AS, Birkbeck TH (1987) The role of toxins in Vibrio infections of bivalve mollusca. Aquaculture 67:244-246

Nottage AS, Birkbeck TH (1990) Interactions between different strains of Vibrio alginolyticus and hemolymph fractions from adult Mytulus edulis. J Invertebr Pathol 56: $15-19$

Paillard C, Maes P (1990) Etiologie de la maladie de l'anneau brun chez Tapes philippinarum: pathogénicité d'un Vibrio sp. Cr Acad Sci, Paris 310:15-20

Pazos F, Santos Y, Magariños B, Bandin I, Nuñez S, Toranzo $A E$ (1993) Phenolypic characteristics and virulence of $V i b$ rio anguillarum-related organisms. Appl environ Microbiol 59:2969-2976

Porter K, Feig Y (1980) The use of DAPI for identifyng and counting aquatic microflora. Limnol Oceanogr 25(5): 943-948

Riquelme C, Chavez P, Morales Y (1994) Evidence of parental bacterial transfer to larvae in Argopecten purpuratus (Lamarck, 1819). Biol Res 27:129-134

Sinderman ( (1990) Principal diseases of marine fish and shellfish, 1 ol 2, 2nd edn. Academic Press, New York, p $41-62$

Sørensen UBS, Larsen JL (1986) Serotyping of Vibrio anguillarum. Appl environ Microbiol 51:593-597

Toranzo AE, Barja JL (1990) A review of the taxonomy and seroepizootiology of Vibrio anguillarum, wath special reference to aquaculture in the northwest of Spam. Dis aquat Org 9:73-82

Toranzo AE, Barja JL (1993) Virulence factors of bacteria pathogenic for coldwater fish. A Rev Fish Dis 3:5-36

Toranzo AE, Baya AM, Roberson BS, Barja JL, Grimes DJ, Hetrick FM (1987) Specificity of slide agglutination test for detecting bacterial fish pathogens. Aquaculture $67: 81-97$

Toranzo AE, Novoa B. Romalde JL, Nunez S, Devesa S, Marino E, Silva R, Vartinez E, Figueras A, Barja JL (1993) Microflora associated with healthy and diseased turbot (Scophthalmus maximus) from three farms in northwest Spain. Aquaculture 114:189-202

Toranzo AE, Santos Y, Bandim I, Romalde JL, Ledo A, Fouz B, Barja JL (1990) Five-year survey of bacterial fish infections in continental and marine aquaculture in Northwest Spain. World Aquacult 21:91-94

Vial MV, Teuber C. Costabal P. Poblete T, Donoso TG, Gebauer MT (1988) Presencia de Vibrio anguillarum (Canestrini) en el tracto digestivo de Mytilus edulus (Hupe). Biota 4(2):119-124

West PA, Colwell RR (1.984) Identification and classification of Vibrionaceae. An overview. In: Colwell RR (ed) Vibrios in the environment. John Wiley \& Sons, Inc, New York, p $258-363$

Zar JH (1984) Biostatistical analysis, 2nd edn. Prentice-Hall, Englewood Cliffs, NJ

Manuscript first received: March 9, 1994

Revised version accepted: December 7, 1994 